\title{
SAJEST
}

https://doi.org/10.21905/sajest.2016.004

Original Article

Received: June 2014 / Accepted: 1 August 2016

Open Access

Published online: June 2017

\section{Evaluation of Chicken Blood and Maize Stover Compost as a Nitrogen Source for}

\section{Maize}

Pisa Charity ${ }^{1}$, Menas Wuta ${ }^{2} *$

\begin{abstract}
Organic materials are an important source of nutrients for many smallholder farmers. The use of composted organic amendments is constrained by their variability and maturity. The aim of this study was to evaluate the potential of aerobically composted chicken blood and maize stover mixtures on maize $\mathrm{N}$ uptake and to determine the effect on seed emergence in a greenhouse pot experiment. Four composts with proportions of $10 \%, 30 \%, 70 \%$ and $100 \%$ maize stover were used as soil amendments and compared against an unamended soil (control). The greenhouse pot experiment involved planting 10 maize seeds in each pot. Seed emergence percent was determined a week after sowing to ascertain whether the composts had phytotoxic effects. Percent emergence did not differ significantly among treatments $(\mathrm{p}=0.26)$. Two plants were allowed to grow in the pots for five weeks after which maize dry matter yield and foliar analysis followed.
\end{abstract}

Corresponding Author":

${ }^{1}$ Marondera College of Agricultural Science and

Technology, P.O. Box 35, Marondera, Zimbabwe.

${ }^{2}$ Department of Soil Science and Agricultural Engineering, University of Zimbabwe, P. O. Box MP167, Mount Pleasant, Harare, Zimbabwe

Email:wokwawuta@yahoo.com
The foliar samples were analysed for total nitrogen, dry matter yield and cations ( $\mathrm{Mg}, \mathrm{Ca}, \mathrm{K}$ and $\mathrm{Na}$ ). Nitrogen uptake differed significantly among treatments and ranged from $0.27 \%$ to $0.75 \%$. Nitrogen uptake was higher in soils amended with $10 \%$ and $30 \%$ maize stover compost treatments. Dry matter yield also differed significantly ranging from $1.09 \mathrm{~g}$ to $2.2 \mathrm{~g}$ per pot). Uptake of all cations did not differ ( $p>0.05)$ significantly among treatments. The $10 \%$ and $30 \%$ maize stover composts had greater potential to support maize growth as shown by the dry matter yield and total $\mathrm{N}$ concentrations in the plant samples.

Key words: Compost, emergence, maize, nitrogen.

\section{INTRODUCTION}

Organic materials are an important source of nutrients for many smallholder farmers who lack financial resources to purchase mineral fertilisers (Masunga et al., 2016; Steinfield et al., 2006; Rufino et al., 2007). The use of organic amendments is however constrained by their heterogeneity, variability and benefits are not realized immediately after incorporation hence most organic resources show limited increases in crop growth (Vanlauwe, 2004). Organic materials and compost use in crop production is gaining popularity due to the increased appreciation that conventional and intense tillage cropping systems 
result in soil organic matter loss (Chivenge et al., 2009). Incorporation of compost can result in organic matter build up and an increase in organic matter results in an increase in cation exchange capacity (CEC) of soils and also adsorption of soil contaminates (Mando et al., 2005; Vanlauwe, 2004). Nutrients become available to plant roots at a slower rate with compost compared to inorganic fertilisers thus nutrients are retained for longer in soils. In order to develop efficient systems to improve soil nutrient dynamics a balance must be established between crop demands and nutrient supply from the decomposition of organic materials (Munthali et al., 2015). Organic matter decomposition releases these nutrients and is affected by a wide range of factors including soil nutrient content, moisture content, biological activity and organic residue quality. A good quality compost is one that has the capacity to function within natural or managed ecosystem boundaries by restoring and enhancing the potential of the soil to sustain plant and animal productivity (Brinton 2012; Bera et al., 2013; Pisa and Wuta 2013)

Though compost applications have a number of benefits, there have been cases in which composts have had negative impacts on crop growth. Tiquia (2010) reported delayed seedling emergence and reduced crop growth after the incorporation of some compost products. These negative impacts were attributed to the use of unstable or immature compost. Compost maturity determines whether compost can be used in crop production without negative effects due to $\mathrm{N}$ immobilisation, oxygen depletion or the presence of phytotoxic compounds, such as the organic acids; propionic, acetic and butyric acid. Low molecular weight organic acids such as phenolic compounds are responsible for phytotoxic effects of composts on seed germination, emergence and plant growth (Gómez-
Brandón et al., 2008). Monspart-S'enyi (2012) demonstrated that volatile low molecular weight organic acids decreased with composting duration and are associated with early stages of decomposition. Various parameters have been used as compost maturity indices (Gómez-Brandón et al., 2008; Mangkoedihardjo, 2006). Carbon to nitrogen ratio and $\mathrm{NH}_{4}{ }^{+}: \mathrm{NO}_{3}{ }^{-}$ratio can be used to determine compost maturity (Chukwujindu et al., 2006; Mangkoedihardjo, 2006). Electrical conductivity of less than 2.0 mmho, $\mathrm{pH}$ between 6 and 7.5, absence of phytotoxic substances and an $\mathrm{NH}_{4}{ }^{+}: \mathrm{NO}_{3}{ }^{-}$ratio of less than 1:1 (Pant et al., 2011; Radovich et al., 2011), are indices used to determine compost maturity.

Nitrogen is the most limiting nutrient to crop growth in most Zimbabwean soils (Agren et al., 2012; Mapfumo and Giller, 2001) requiring the use of soil amendments. Nitrogen in organic amendments, such as compost, is in organic form (Bremmer, 1996) therefore the fertilising value of the compost is evaluated on the basis of its ability to release mineral $\mathrm{N}$ to meet crop requirements. It is therefore necessary to determine the content as well as the potential of the compost to release mineral N (Pisa and Wuta, 2013). The ability to release $\mathrm{N}$ has to be balanced against contribution of the stable soil organic matter pool which contributes more to long-term soil fertility. Handayanto, et al. (1997) explored the possibility of synchronising nutrient release and plant uptake through composting and mixing residues of different quality. The intention is to increase $\mathrm{N}$ release from low quality organics by mixing them with high quality organic to meet plant requirements. There is thus a possibility of using mature composts along with mineral fertilisers or mixtures of raw waste in proportions which 
moderate the nutrient release pattern of the mixture favourably.

In Zimbabwe, there has been limited research on composting and the ability of the compost products to supply nutrients. Research done include composting of household wastes as soil amendments for peri-urban farming systems (Mhindu et al., 2013) and composting of poultry wastes to produce an organic fertilizer for maize and horticultural crops (Pisa, 2007; Pisa and Wuta, 2013). However, there has been no study that has evaluated the potential of chicken blood and maize stover compost as a nitrogen source in crops. Large quantities of blood are produced in Zimbabwe's small abattoirs and slaughterhouses. The blood is held in lagoons and holding tanks for a long time before disposal (Pisa, 2007; Pisa and Wuta, 2013) as fresh blood cannot be spread over land. Blood is rich in $\mathrm{N}$ and other essential plant nutrients (Mittal, 2007) and therefore can be used as a source of plants nutrients. It cannot be however applied directly to land due to associated environmental pollution problems such as the presence of pathogens, eutrophication, groundwater pollution, acid deposition, and high ammonia and nitrate concentration in the soil (Akinro et al., 2009, Singh et al., 2014). To avoid pollution composting a mixture of blood and maize stover was found to produce stable compost with little or no environmental problems. Pisa and Wuta 2013 determined the composting performance of chicken blood and maize stover but the potential of the finished compost to support plant growth was however not done The compost produced was assumed to be stable and environmentally friendly with no pathogens, a $\mathrm{C}: \mathrm{N}$ ratio less than the critical 20:1 (Marthur et al., 1993, Kokkora et al., 2010) and an $\mathrm{NH}_{4}-\mathrm{N}: \mathrm{NO}_{3}-\mathrm{N}$ ratio of less than 0.16 (Pant et al., 2011; Radovich et al., 2011). The aim of this study was to evaluate the potential of aerobically composted chicken blood and maize stover mixtures as sources of nitrogen and also determine their effect on maize seed emergence.

\section{MATERIALS AND METHODS}

Chicken blood and maize stover were aerobically composted (Pisa and Wuta, 2013) and the finished product was used in this study. Chicken blood from slaughter houses was mixed with maize stover at different proportions of $10 \%, 30 \%, 70 \%$ and $100 \%$ maize stover by weight and composted in composting bins measuring $1 \mathrm{~m}^{3}$ over 72 days (Pisa, 2007; Pisa and Wuta, 2013). The final composts were tested in a greenhouse pot experiment at the University of Zimbabwe using sandy soils from Churu farm (1390 masl; 30 ${ }^{\circ} 55^{\prime} \mathrm{E}$ $\& 17^{\circ} 56^{\prime}$ S) in Harare. The finished composts and the soil were characterised before use.

\subsection{Soil sampling and analysis}

Soils were collected from Churu farm by randomly taking five representative soil sub samples from a depth of 0 to $20 \mathrm{~cm}$ using a soil auger. Bulk soil samples were also collected and mixed to make a total of $50 \mathrm{~kg}$ of soil for use in the greenhouse experiment. The composite auger sample was air dried and sieved to pass through a $2 \mathrm{~mm}$ sieve. Soils were analysed for texture, $\mathrm{pH}$, organic carbon, available $\mathrm{P}$ and $\mathrm{N}$. Soil texture was determined using the hydrometer method after dispersing the soil using sodium hexa-metaphosphate (Anderson and Ingram, 1993). Soil pH was measured using the $\mathrm{CaCl}_{2}$ method (Okalebo et al., 2002) using a Jenway model 3510 pH meter.

Soil organic carbon was determined using the modified Walkley-Black method (Anderson and Ingram, 1993) with external heating. Total $\mathrm{N}$ was 
extracted from a soil sample by wet digestion using concentrated sulphuric acid, selenium powder, lithium sulphate and hydrogen peroxide mixture (Anderson and Ingram, 1996). Total soil $\mathrm{N}$ was measured colorimetrically at a wavelength of 650 nm (Okalebo et al., 2002).

\subsection{Compost sampling and analysis}

Composite samples were collected from respective compost bins by pooling 5 sub-samples from random positions of each bin at the end of the composting period. Before collecting samples, compost in each bin was thoroughly mixed. The compost samples were oven dried at $60^{\circ} \mathrm{C}$ for 48 hours before grinding them to pass through a $2 \mathrm{~mm}$ sieve. Composts were analysed for total $\mathrm{N}$, mineral $\mathrm{N}$, total nutrients ( $\mathrm{Ca} \mathrm{Mg} \mathrm{Na}$ and $\mathrm{K}$ ), organic carbon, $\mathrm{pH}$, electrical conductivity and ash after oven drying using standards methods described in Okalebo, et al., 2002).

Mineral N (ammonium-N and nitrate-N) was extracted from compost samples by shaking $10 \mathrm{~g}$ of fresh compost in $100 \mathrm{ml}$ of $0.5 \mathrm{M} \mathrm{K}_{2} \mathrm{SO}_{4}$ on a reciprocal shaker for one hour. The mixture was filtered through a Whatman's No 42 filter paper. Ammonium-N was determined in an aliquot $(0.2$ $\mathrm{ml}$ ) of the filtrate after colour development with sodium nitro-prusside and nitrate- $\mathrm{N}$ was determined in a separate aliquot $(0.5 \mathrm{ml})$ after colour development with 5\% salicylic acid using a spectrophotometer (Okalebo, et al., 2002).

Total $\mathrm{N}$, total nutrients ( $\mathrm{Ca} \mathrm{Mg} \mathrm{Na}$ and $\mathrm{K}$ ), organic carbon, $\mathrm{pH}$, electrical conductivity and ash content were determined on ground oven dried compost samples. Total $\mathrm{N}$ was extracted from compost sample by wet digestion using concentrated sulphuric acid, selenium powder, lithium sulphate and hydrogen peroxide mixture (Anderson and
Ingram, 1996). The hydrogen peroxide oxidises the organic matter while selenium powder acts as the catalyst for the process. Sulphuric acid completed the oxidation at elevated temperatures. Total $\mathrm{N}$ was determined in an aliquot of the digest after colour development with sodium nitroprusside using a spectrophotometer (Okalebo et al., 2002).

Electrical conductivity and $\mathrm{pH}$ were determined on water extracts (1:10 air-dried compost raw material: water) as outlined by Smith and Hughes (2002). The ground samples were shaken in distilled water on a reciprocal shaker for 30 minutes and left to stand overnight. $\mathrm{pH}$ was measured using a Jenway model $3510 \mathrm{pH}$ meter and EC was read on an EcoScan Con 5 electrical conductivity meter. Ash and organic matter content were determined as residual mass and weight loss respectively on ignition at $550^{\circ} \mathrm{C}$ for 12 hours in a muffle furnace. Organic carbon was calculated from weight loss on ignition using equation 1 :

$\% \mathrm{C}=($ weight loss on ignition $\mathrm{x} 100) / 1.8$

(Haug, 1980) Equation 1

Total cations $(\mathrm{Ca}, \mathrm{Mg}, \mathrm{Na}$ and $\mathrm{K}$ ) were determined in ash by adding 2 to 3 drops of distilled water.

Hydrochloric acid $(50 \% ; 2.0 \mathrm{ml})$ was added to the sample and the sample heated to dryness on a block heater. Nitric acid $(25 \% ; 5.0 \mathrm{ml})$ was added to dissolve the sample. The dissolved sample was transferred to a $50 \mathrm{ml}$ volumetric flask and the volume made to the mark. After settling a clear supernatant $(1.0 \mathrm{ml})$ was pipetted into a $50 \mathrm{ml}$ volumetric flask. Strontium chloride $(1 \% ; 25 \mathrm{ml})$ was added followed by distilled water $(24 \mathrm{ml})$ and the mixture was thoroughly mixed. Calcium and magnesium were read on an atomic absorption spectrophotometer (AAS) at wavelengths of 422.7 $\mathrm{nm}$ and $285.2 \mathrm{~nm}$ respectively. Sodium and 
potassium was determined using flame emission spectrophotometry.

\subsection{Green house experiment layout and procedure}

A green house pot experiment was established using air dried Churu farm soil to test the maturity of the finished compost derived from chicken blood and maize stover. The compost was used as a soil amendment. Maize variety SC 513, an early maturing variety was grown in pots filled with amended sandy soil. The pots used measured $23 \mathrm{~cm}$ in diameter and $23 \mathrm{~cm}$ depth. The soil was first sieved to pass through a $2 \mathrm{~mm}$ sieve before use. The soil was amended with an equivalent rate of $100 \mathrm{~kg}$ of $\mathrm{N}$ per hectare. Maize $\mathrm{N}$ requirement ranges from $90-120 \mathrm{~kg} \mathrm{~N} / \mathrm{Ha}$ (FAO, 2006). Treatments used are shown in Table 1.

Composts were ground to pass through a $2 \mathrm{~mm}$ sieve before mixing with $3 \mathrm{~kg}$ of soil. The treatments were replicated three times and pots were placed in the greenhouse in a completely randomised design. A total of 15 pots were used. The soil and the composts were thoroughly mixed and ten maize seeds placed into each pot. After determining percent emergence by counting the number of emerged seeds two weeks after sowing, two plants were left in each pot. The remaining plants were allowed to grow for five weeks because at between four and five weeks plant nutrients are well distributed in the plant and this is when optimum nutrient uptake from the soil takes place. Soil moisture was adjusted regularly according to plant requirements to avoid moisture stress and leaching the soils. The above ground plant parts were harvested at five weeks and oven dried at $60 \mathrm{oC}$ for 48 hours. Oven-dried maize samples were ground and analysed for total $\mathrm{N}, \mathrm{Mg}, \mathrm{Ca}$ and $\mathrm{K}$ using the same methods outlined for the compost samples (Okalebo et al., 2002).

\subsection{Statistical analysis}

Statistical analysis was done using Genstat 6 package, (Genstat, 2003). Treatment means were calculated and a general ANOVA was used to determine whether there were significant differences among treatments at a confidence interval of $95 \%$. Least significant difference (LSD) was used to determine treatments that were significantly different.

\section{RESULTS}

\subsection{Characterisation of soil and the final compost}

Tables 2 and 3 show the different chemical properties of the composts and the soil used for the greenhouse pot experiment. Total and mineral $\mathrm{N}$ content decreased in the order $10 \%>30 \%>70 \%>$ $100 \%$ in the maize stover compost treatments. The $\mathrm{C}: \mathrm{N}$ ratio of the $10 \%$ and $30 \%$ maize stover compost treatments where below the critical 20:1 ratio while the $70 \%$ and $100 \%$ where higher.

\section{Percent Seed emergence}

Seed emergence percentage did not significantly differ among treatments $(P=0.260$, Table 4). Most of the planted seeds germinated and emerged well indicating that there were no problems. 
Table 1. The treatments used in the greenhouse pot experiment

\begin{tabular}{cl}
\hline Treatment & Proportions of chicken blood and maize stover in the finished compost \\
\hline 1 & $10 \%$ maize stover $+90 \%$ chicken blood \\
3 & $30 \%$ maize stover $+70 \%$ chicken blood \\
4 & $70 \%$ maize stover $+30 \%$ chicken blood \\
5 & No amendment (control) \\
\hline
\end{tabular}

Table 2. Chemical properties of soil amendments

\begin{tabular}{lcccc}
\hline Chemical properties & $\mathbf{1 0 \%}$ stover & $\mathbf{3 0 \%}$ stover & $\mathbf{7 0 \%}$ stover & $\mathbf{1 0 0 \%}$ stover \\
\hline Total N (\%) & 3.75 & 3.43 & 2.41 & 0.98 \\
\hline Ammonium -N ppm & 146.9 & 62.36 & 55.9 & 35.4 \\
\hline Nitrate - N ppm & 1.52 & 0.94 & 0.44 & 0.37 \\
Total cations (ppm) & 43.99 & 40.78 & 33.60 & 30.40 \\
Organic Matter (\%) & 50.6 & 47.7 & 55.0 & 59.00 \\
pH & 6.03 & 6.52 & 6.49 & 7.74 \\
EC (mScm & $-1)$ & 3.46 & 2.88 & 2.14 \\
Ash Content $(\%)$ & 4.05 & 14.54 & 15.04 & 15.06 \\
C/N ratio & 16.38 & 13.92 & 22.84 & 60.20 \\
\hline
\end{tabular}

Table 3. Selected chemical soil properties

\begin{tabular}{ll}
\hline Chemical properties & \\
\hline$\%$ Clay & 5 \\
$\%$ Silt & 3 \\
$\%$ Sand & 92 \\
Texture & Sandy \\
$\mathrm{pH}\left(\mathrm{CaCl}_{2}\right.$ & 5.2 \\
$\mathrm{OC}(\%)$ & 1.6 \\
Available P (ppm) & 11 \\
Available N (ppm) & 23 \\
\hline
\end{tabular}

Table 4. Percent seed emergence for each soil amendment

\begin{tabular}{lc}
\hline Percent maize stover in compost amendment & \% Seed emergence \\
\hline $10 \%$ Maize stover & 96.7 \\
$30 \%$ Maize stover & 100 \\
$70 \%$ Maize stover & 93.3 \\
$100 \%$ Maize stover & 86.7 \\
Control & 100 \\
\hline Least significance difference & 14.09 \\
\hline
\end{tabular}


Maize dry matter yield

Maize dry matter yield differed significantly among treatments $(\mathrm{p}<0.05)$ and was in the order $10 \%>$ $30 \%>70 \%>100 \%>$ control (Figure 1). The plants grown in the soil amended with $10 \%$ and $30 \%$

\section{Foliar analysis}

\section{Total Nitrogen}

Mean $\mathrm{N}$ concentration in plant samples increased with a decrease in the proportion of maize stover in the compost. Nitrogen values were in the order $10 \%>30 \%>70 \%>100 \%>$ control (Figure 2). There were significant differences $(p<0.001)$ among treatments in terms of $\mathrm{N}$ concentration with the plants growing in the soil amended with compost derived from $10 \%$ maize stover treatment having the greatest $\mathrm{N}$ concentration $(0.75 \%)$ and those in the control the least $(0.27 \%)$.

However, there was no significant difference in $\mathrm{N}$ concentration between the soils amended with the $70 \%$ and $100 \%$ maize stover compost and the maize stover final compost had greater biomass. These were significantly different from the $70 \%$, $100 \%$ and control treatments.

\section{Nutrient content in maize plant samples}

control. Total cation $(\mathrm{Mg}, \mathrm{Ca}, \mathrm{K}$ and $\mathrm{Na}$ ) uptake did not differ significantly among treatments (p.> 0.05) (Figure 4). The control, however, had the highest total cation content and was significantly different from the soils amended with compost.

\section{DISCUSSION}

Maize seed emerged well for all the treatment indicating that the amendments did not have phytotoxic organic compounds, such as the propionic, acetic and butyric acid which hinder germination and seed emergence. Baziramakenga and Simard (1998) demonstrated that volatile low molecular weight organic acids decreased with composting duration and are associated with early stages of decomposition.

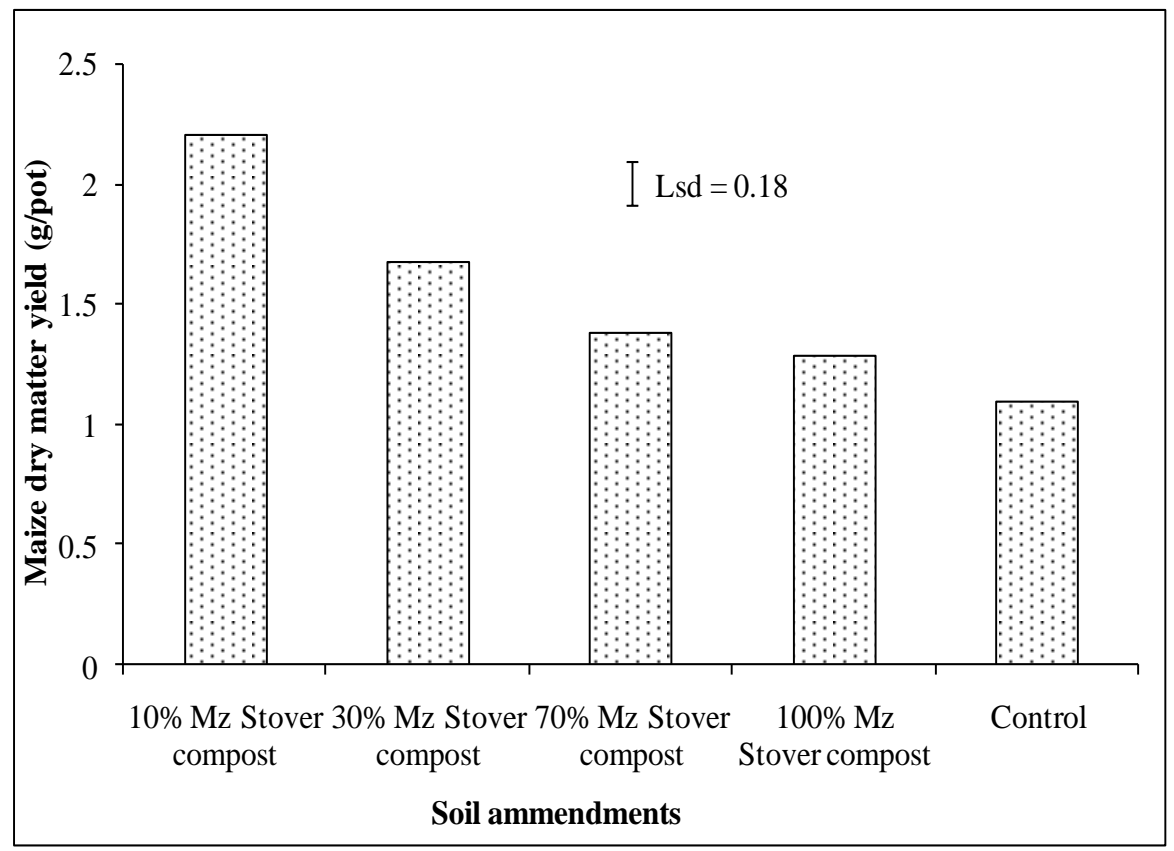

Figure 1: Effects of final composts on maize dry matter yield at five weeks after emergence in the greenhouse pot. 


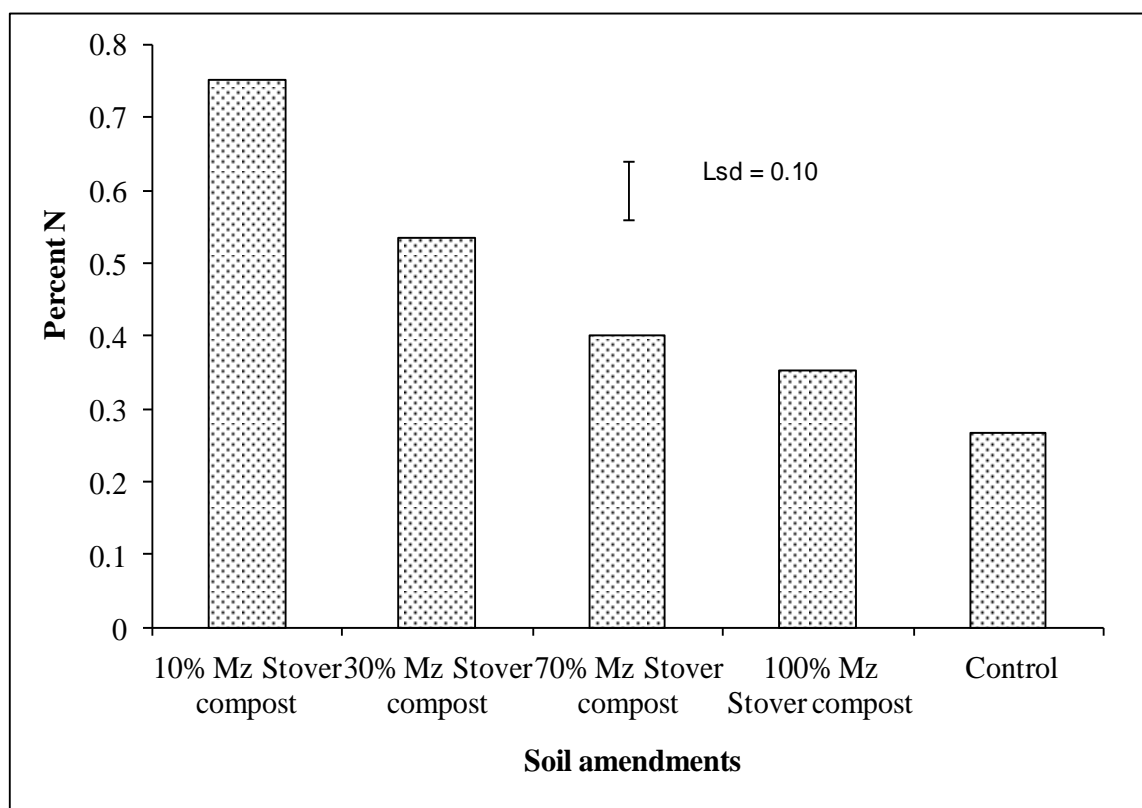

Figure 2: Total nitrogen uptake by plants grown in soils amended with different chicken blood finished compost. (Data points are the mean of the three replicates)

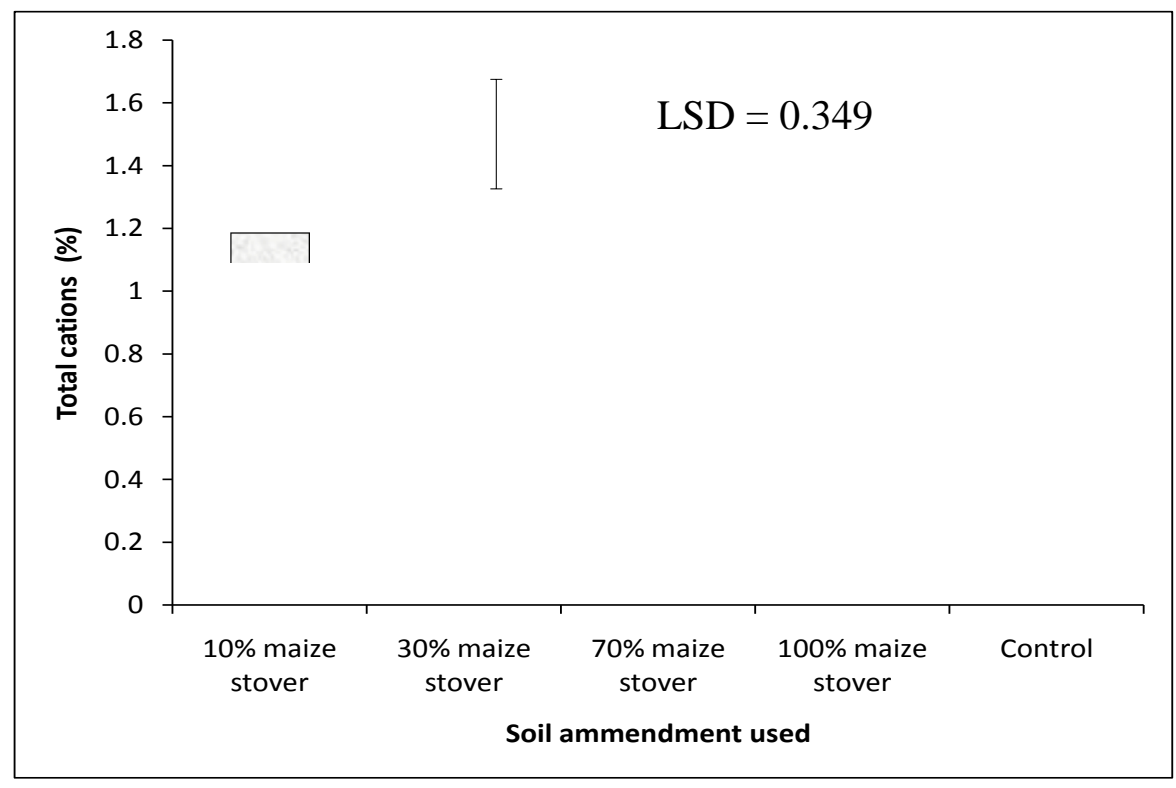

Figure . Total cation uptake by plants grown in soils amended with different chicken blood finished compost. (Data points are the mean of the three replicates)

Tiquia and Tam (1998), Tiquia et al., (1996) and Terman et al., (1973), reported that the application of immature composts inhibited seed germination, emergence and plant growth due to phytotoxic compounds. Nitrogen availability in the soils amended using the $70 \%$ and $100 \%$ treatments was low compared to the $10 \%$ and $30 \%$ treatments. This could have been due to differences in $\mathrm{N}$ mineralization as $\mathrm{C}: \mathrm{N}$ ratios differed significantly, $\mathrm{P}<0.05)$. Rate of nitrogen mineralization is 
affected mainly by the $\mathrm{C}: \mathrm{N}$ ratio of the organic amendment. Residues with low $\mathrm{C}: \mathrm{N}$ ratios tend to exhibit net $\mathrm{N}$ mineralization, while residues with high $\mathrm{C}: \mathrm{N}$ ratio exhibit immobilization (Mohanty et al., 2010;). The 10\% and 30\% treatments had C:N ratios of 13.52 and 13.92 respectively. These were below the critical C:N ratio of 20:1 (Mupondi et al., 2006) and thus mineralised better and faster than the other treatments making more $\mathrm{N}$ available for uptake. The initial C:N ratios of the $70 \%$ and $100 \%$ maize stover treatments were 22.84 and 60.20 respectively. The $10 \%$ and $30 \%$ composts also had more available $\mathrm{NH}_{4}-\mathrm{N}$ and $\mathrm{NO}_{3}-\mathrm{N}$ (Table 2). However, the concentrations of $\mathrm{N}$ for all the treatments were lower than the adequate plant $\mathrm{N}$ tissue concentration reported by Okalebo et al., (1999). Nitrogen should range from 3.5 to $5 \%$ at 5 weeks for maize (Okalebo et al., 1999). in fields after the application of organic amendments. Research has also shown that mineralisation occurs in multiple phases after compost application depending on the decompostibility of the composts (Hargreaves et al., 2008; Kokkora et al., 2010). This means there is a non-steady $\mathrm{N}$ release rate even if compost is expected to result in net $\mathrm{N}$ mineralisation at $\mathrm{C}: \mathrm{N}$ ratio below 15. Nyamangara and Giller, (2003), reported $\mathrm{N}$ deficiency in maize during early plant growth (6 weeks after planting). For this study the maize crop could have been left to grow over a longer period. Most studies on compost mineralisation have been done over longer periods. Murillo et al., (1995) found 22\% mineralisation over a 22 week period of incubation while Iglesias and Alvarez, (1993) found 21\% mineralisation over a 6 month pot study.

The low $\mathrm{N}$ recoveries suggest slow mineralisation rates. Large compost applications would be required to significantly increase short term soil $\mathrm{N}$ supply (Hartz et al., 2000) or combine with
Composting reduces $\mathrm{N}$ mineralisation rates of organic waste. It stabilises $\mathrm{C}$ and $\mathrm{N}$ in the organic soil amendment (Nyamangara et al., 1999). Kokkora et al., (2010), Hargreaves et al., (2008ab), and Hartz et al. (2000), however, reported that mineralisation rates of composts vary nearly as widely as those of uncomposted manure. Castellanos and Pratt (1981) found N mineralisation rates ranging from 4 to $35 \%$ in a 10 month assay for manure composts, while Douglas and Magdoff (1991) reported that three manure composts had net $\mathrm{N}$ immobilization over 67 day incubation period.

The maize plants were stunted and yellow in colour and this could have been due to the inadequate $\mathrm{N}$ concentration in the soil. Short term immobilisation could be attributed to the deficiency symptoms observed. This could explain crop $\mathrm{N}$ deficiencies inorganic fertiliser (Nyamangara et al., 2003). Compost and manure amendment trials can indicate the value of organic amendments in long term soil building and their limitations in enhancing short term $\mathrm{N}$ availability.

\section{CONCLUSION}

From the study, the composts derived from mixtures of chicken blood and maize stover with initial proportions of $10 \%$ and $30 \%$ maize stover had greater potential to support maize growth as shown by the dry matter yield and total $\mathrm{N}$ concentrations in the plant samples. Total cations $(\mathrm{Mg}, \mathrm{Ca}, \mathrm{K}$ and $\mathrm{Na}$ ) did not show significant difference among treatments. Further studies where the composts are combined with mineral nitrogen fertilizer to enhance the supply of $\mathrm{N}$ are recommended because the $\mathrm{N}$ from the composts were inadequate. Maize seed emerged well for all the treatments indicating that the amendments did not have phytotoxic organic compounds. 


\section{ACKNOWLEDGEMENTS}

The authors wish to thank the poultry processing companies in Harare, Zimbabwe, for giving access to their processing plants and for providing the chicken blood for the experiments. This work was supported by a grant from the Regional Universities Forum for Capacity Building in Agriculture (RUFORUM).

\section{REFERENCES}

Agren, G.I.J. Wetterstedt, A.M. and Billberger, M.F.K. 2012. Nutrient limitation on terrestrial plant growth - modeling the interaction between nitrogen and phosphorus; New Phytologist 194: 953-960 doi: 10.1111/j.1469-8137.2012.04116.x

Anderson, J.M. and Ingram, J.S.I. 1993. Tropical Soil Biology and Fertility: A Handbook of Methods. CAB International, Wallingford, UK.pp. 171.

Anderson, J.M. and Ingram, J.S.I. 1996. Tropical Soil Biology and Fertility - A Handbook of Methods. 2nd Edition. Information Press, Eynsham-UK- Cab International. pp. 221.

Akinro A.O., Ologunagba I.B. and Yahaya, O. 2009. Environmental implications of unhygienic operation of a city abattoir in Akure, Western Nigeria, ARPN Journal of Engineering and Applied Sciences, Vol. 4(9). ISSN 1819-6608

Baziramakanga, R. and Simard, R.R. 1998. Low Molecular Weight Aliphatic Acid Contents of Composted Manures. Journal of Environmental Quality 27: $557-561$. doi:10.2134/jeq1998.00472425002700030012x
Bera, R. Datta, A., Bose, S., Dolui, A.K., Chatterjee, A.K., Dey, G.C., Barik, A.K., Sarkar, R.K., Majumdar, D. and Seal, A. 2013. Comparative Evaluation of Compost Quality, Process Convenience and Cost under Different Composting Methods to assess their Large Scale Adoptability Potential as also Complemented by Compost Quality Index. International Journal of Scientific and Research Publications, Volume 3, Issue 6. ISSN 2250-3153

Bremmer, J.M. 1996. Nitrogen-Total. In: Weaver, R.W, Angle, P., Bezdicek, Smith,S. Tabatabai, and Wollum (Eds) Methods of Soil Analysis Part 3 Chemical Methods. Soil Science Society of Agronomy. Madison Wsconsin, USA. pp. 1085 1121.

Brinton, W., Bonhotal, J. and Fiesinger, T. 2012. Compost sampling for nutrient and quality parameters: Variability of sampler, timing and pile depth. Compost Science and Utilisation 20: 141 149. doi.org/10.1080/1065657X.2012.10737039

Castellanos, J.Z. and Pratt, P.F. 1981. Mineralization of Manure Nitrogen-Correlation with Laboratory Indexes. Soil Science Society of America Journal 45:354-357.

doi:10.2136/sssaj1981.03615995004500020025x

Chivenge, P., Vanlauwe, B., Gentile, R., Wangechi, H., Mugendi, D., van Kessel, C. and Six, J. 2009. Organic and Mineral Input Management to Enhance Crop Productivity in Central Kenya. Journal of Agronomy 101:1266-1275 doi:10.2134/agronj2008.0188x. 
Chukwu, O., Adeoye, P.A., Chidiebere, I. 2011. Abattoir wastes generation, management and the environment: a case of Minna, North Central Nigeria. International Journal of Biosciences (IJB) Vol. 1 (6): 100-109. ISSN: 2220-6655 (Print) 22225234 (Online)

Chukwujindu, M.A., Cegun, A., Emuh, N. and Isirmiah, N.O. 2006. Compost Maturity Evaluation and its Significant to Agriculture. Pakistan Journal of Biological Science 9: 2933-2944. ISSN 10288880 .

Douglas, B.F. and Magdoff, F.R. 1991. An Evaluation of Nitrogen Mineralization Indices for Organic Residues. Journal of Environmental Quality. 20:368-372. doi:10.2134/jeq1991.00472425002000020006x

FAO, 2006 Fertiliser Use by Crops in Zimbabwe. Land and Plant Nutrition Management Service, Food and Agriculture Organisation of the United Nations, Rome, Italy pp 36. ISBN 978-92-5105592-2

GENSTAT, 2003. “GENSTAT Statistical Package," 8th Edition, VSN International, Hertfordshire

Gómez-Brandón, M, Lazcano, C. and Jorge Domínguez, J. 2008. The Evaluation of Stability and Maturity During the Composting of Cattle Manure. Chemosphere 70: 436-444. doi: 10.1016/j.chemosphere.2007.06.065

Hargreaves, J.C., Adl, M.S., Warman, P.R. and Vasantha Rupasinghe H.P. 2008. The effects of organic amendments on mineral element uptake and fruit quality of raspberries, Plant and soil
308(1): 213 -226 doi.org/10.1007/s11104-008-

9621-5

Hargreaves, J.C., Adl M.S., Warman, P.R. 2008. A review of the use of composted municipal solid waste in Agriculture. Agricultural Ecosystems and the Environment 123: 1-14 doi.org/10.1016/j.agee.2007.07.004

Handayanto, E., Cadisch, G. and Giller, K.E. 1997. Regulating N Mineralisation from Plant Residues by Manipulating bf Quality, In: Cadisch, G. and Giller, K.E (Eds.) Driven By Nature. Plant Litter Quality and Decomposition, CAB International. Wallingford. pp. $175-185$.

Hartz, T., Mitchell, J.P. and Giannini, C. 2000. Nitrogen and Carbon Mineralisation Dynamics of Manures and Composts. HortScience 35 (2): 209212.

Haug, R.T. 1980. Compost Engineering; Principles and Practice. Technomic Publishing Co., Inc. ISBN 10: 0250403471/ ISBN 13: 9780250403479

Iglesias-Jimenez, E. and Alvarez, C.E. 1993. Apparent Availability of Nitrogen in Composted Municipal Refuse. Biology and Fertility of Soils 16:313-318. doi.org/10.1007/BF00369312

Keeling, A.A, Paton, I.K. and Mullet, J.A.J. 1994. Germination and Growth of Plants in Media Containing Unstable Refuse Derived Compost. Soil Biology and Biochemistry 26: 767 - 772. doi.org/10.1016/0038-0717(94)90271-2

Kirchmann, H. and Widen, P. 1994. Separately Collected Organic Household Wastes: Chemical 
Composition and Composting Characteristics. Swedish Journal of Agricultural Research 24: 3-12.

Kokkora M.I., Antille D.L., Tyrrel, S.F. 2010. Considerations for recycling of compost and biosolids in agricultural soils. In: Dedousis A.P and Bartzanas T (eds) Soil engineering, (Soil Biology series); Springer-Verlag, Berlin Heidelberg doi 10.1007/978-3-642-03681-1_13

Mando, A., Ouattara, B., Somado, A.E., Wopereis, M.C.S., Stroosnijder, L., Breman, H., 2005. Longterm effects of fallow, tillage and manure application on soil organic matter and nitrogen fractions and on sorghum yield under SudanoSahelian conditions. Soil Use and Management 21, 25-31.doi.org/10.1111/j.1475-743.2005.tb00103.x

Mangkoedihardjo, S. 2006. Re-evaluation of Maturity Indices for Compost. Journal of Applied Sciences and Environmental Management 10 (3): 83-85. doi.org/10.4314/jasem.v10i3.17324

Mapfumo, P. and Giller, K.E. 2000. Soil Fertility Management Strategies by Smallholder Farmers in Semi-Arid Areas of Zimbabwe. International Crops Research Institute for Semi-Arid Tropics. Food and Agriculture Organisation of the United Nations, Rome, Italy pp. 53.

Masunga R.H., Uzokwe, V.N., Mlaya, P.D. Odeh, I., Singhd, A., Buchane, D., De Nevee, S. 2016. Nitrogen mineralization dynamics of different valuable organic amendments commonly used in agriculture. Applied Soil Ecology 101: 185-193 doi.org/10.1016/j.apsoil.2016.01.006
Mhindu, R.L., Wuta, M. and Ngorima, E. 2013. Composting of Selected Organic Wastes from PeriUrban Areas of Harare, Zimbabwe. International Journal of Recycling of Organic Waste in agriculture 2:14. doi.org/10.1186/2251-7715-2-14

Mittal, G.S. 2007. Regulations related to land application of abattoir Wastewater and residues. School of engineering, University of Guelph, Guelph, Ontario, N1G 2WI, Canada ISSN16821130

Mohanty, M., Probert, M.E., Sammi Reddy, K., Dalal, R.C., Subba Rao, A. and Menzies, N.W. 2010. Modelling N Mineralization from High C: N Rice and Wheat Crop Residues, 19th World Congress of Soil Science, Soil Solutions for a Changing World 1 - 6 August 2010, Brisbane, Australia.

Monspart-S'enyi, J. 2012. Fruit Processing Waste Management. In: Sinha, N., Sidhu, J., Barta, J., Wu, J., and Cano, M. P. 2012. Handbook of Fruits and Fruit Processing, pp. 712. Wiley-Blackwell, Chichester, UK. ISBN: 978-0-8138-0894-9

Munthali, M.G., Gachene, C.K.K, Karanja, N.K. and Sileshi, G.W. 2015. Decomposition Rates and Nutrient Release Patterns of Tephrosis Vogelii and Tephrosia Candida Residues in Malawi. International Journal of Plant Science and Ecology 1 (2): 26-35 http://www.aiscience.org/journal/ijpse

Mupondi, L.T, Mnkeni, P.N.S and Brutsch, M.O. 2006. The Effects of Goat Manure, Sewage sludge and Effective Micro-Organisms on the Composting of Pine Bark. Compost Science and Utilisation 
14(3):201-210

doi.org/10.1080/1065657X.2006.10702284

Murillo, J.M., Lopez, R., Cabrera, F. and. MartinOlmedo, P. 1995. Testing a Low-Quality Urban Compost as a Fertilizer for Arable Farming. Land Use and Management 11:127-131. doi.org/10.1111/j.1475-2743.1995.tb00510.x

Nyamangara, J., Piha, M.I. and Kirchmann, H. 1999. Interactions of Aerobically Decomposed Cattle Manure and Nitrogen Fertiliser Applied to Soil. Nutrient Cycling In Agro-Ecosystems 54: 183-188. doi.org/10.1023/A:1009794416012

Nyamangara, J., Piha M.I. and Giller, K.E. 2003. Effects of Combined Cattle Manure and Mineral Nitrogen on Maize Uptake and Grain Yield. African Crop Science Journal 11(4): 289-300. doi.org/10.1080/02571862.2005.10634682

Okalebo, J.R., Palm, C.A., Gichiru, M., Owuor, J.O., Othieno, C.O. and Munyampundu, A. 1999. Use of Wheat Straw, Soybean Trash and Nitrogen Fertilizer for Maize Production in the Kenyan Highlands. African Crop Science Journal 7(4):433440. doi.org/10.4314/acsj.v7i4.27736

Okalebo, R.J., Gathua, K.W. and Woomer, P.L. 2002. Laboratory Methods of Soil and Plant Analysis: A Working Manual. Second Edition. The Sustainable Agriculture Centre for Research Extension and Development in Africa, Bungoma and Nairobi, Kenya.
Ozores-Hampton, M., Obrza, T. and Hochmuth, G. 1998. Using Composted Wastes On Florida Vegetable Crops. HortTechnology 8: 130-137.

Palm, C.A., Myers, R.J. and Nandwa, S.M. 1997. Combined Use of Organic and Inorganic Nutrient Sources for Soil Fertility Maintenance and Replenishment. In: Buresh R.J., Sanchez O.A and Calhoun F. (Eds). Replenishing Soil Fertility in Africa. SSSA Publications.

Pant, A., Radovich, T.J.K., Hue, A. and Arancan, N.Q. 2011. Effects of Vermicompost Tea (Aqueous Extract) on Pok-Choi.Yield, Quality and Soil Biological Properties. Compost Science and Utilization 19: 279-292. doi.org/10.1080/1065657X.2011.10737010

Pisa, C. 2007. Composting of Chicken Blood and Maize Stover as a Waste Management Strategy to Produce a Nitrogen Rich Soil Amendment. MSc. Thesis, Department of Soil Science and Agricultural Engineering. Faculty of Agriculture, University of Zimbabwe, Harare, Zimbabwe.

Pisa, C. and Wuta, M. 2013. Evaluation of Composting Performance of Mixtures of Chicken Blood and Maize Stover in Harare, Zimbabwe. International Journal of Recycling of Organic Waste in Agriculture. 2:5. doi.org/10.1186/2251$7715-2-5$

Qian, P. and Schoenau, J. 2002. Availability of Nitrogen in solid Manure Amendments with Different C:N ratios. Canadian Journal of Soil Science 82, 219-225. doi.org/10.4141/S01-018

Radovich, T., Hue, N. and Pant, A. 2011. Compost Quality. In: Radovich, T.,Arancon, N. Tea Time in 
the Tropics - a handbook for compost tea production and use. College of Tropical Agriculture and Human Resources, University of Hawaii. pp. 8-16.

Rufino, M.C., Tittonell, P., van Wijk, M.T., Castellanos-Navarrete, A., Delve, R.J., de Ridder, N. and Giller, K.E. 2007. Manure a key resource within smallholder farming systems, analysing farmscale nutrient cycling efficiencies with the NUANCES framework, Livestock Science 112: 273-287. doi.10.1016/j.livsci.2007.09.011

Singh, A.L., Jamal, S., Baba, S.A. Md., Islam, M. 2014. Environmental and Health Impacts from Slaughter Houses Located on the City Outskirts: A Case Study. Journal of Environmental Protection 5: 566-575. doi: 10.4236/jep.2014.56058

Smith, D.C. and Hughes, J.C. 2002. Changes in Chemical Properties and Temperature During the Degradation of Organic Waste Subjected to Simple Composting Protocols Suitable for Small-Scale Farming and The Quality of the Mature Compost. South African Journal of Plant and Soil 19:53- 60. doi.org/10.1080/02571862.2002.10634439

Steinfield, H., Gerber, P., Wassenaar, T., Caste, V.L., Rosales, M., de Haan, C. 2006; Livestock long Shadow; FAO Rome Italy. ISBN 978-92-5105571-7

Terman, G.L., Soileau, J.M and Allen, S.E. 1973. Municipal Waste Compost: Effects on Crop Yields and Nutrient Content in Greenhouse Pot Experiments. Journal of Environmental Quality 2: 84-90. doi:10.2134/jeq1973.00472425000200010010x
Tiquia, S.M. 2010. Reduction of Compost Phytotoxicity during the Process of Decomposition. Chemosphere, 79 (5): 506-512. 10.1016/j.chemosphere.2010.02.040

Tiquia, S.M. and Tam, N.F.Y .1998. Elimination of Phytotoxicity during Co - Composting of Spent Pig Manure, Sawdust Litter and Pig Sludge. Bioresource Technology 65: 43-49. doi.org/10.1016/S0960-8524(98)00024-8

Tiquia, S.M., Tam, N.F.Y and Hodgkiss, I.J. 1996. Effects of Composting on Phytotoxicity of Spent Pig-Manure Sawdust Litter. Environmental Pollution. 93, 249-256. doi.org/10.1016/S02697491(96)00052-8

Vanlauwe, B. 2004. Integrated Soil Fertility Management Research at TSBF: The Framework, The Principles and Their Applications. In: Bationo, A. 2004.Managing Nutrient Cycles to Sustain Soil Fertility in Sub-Saharan Africa. pp. 25-42. ISBN:978-92-9059-261-7 